\title{
The Role of Utilizing Water Hyacinth as Mulch: The Case of Bora Woreda, East Shewa Zone, Ethiopia
}

\author{
Biruk Gobena* and Mohammed Berhanu \\ Environmental Pollution Management Research Directorate, Ethiopian Environment and Forest Research Institute, Ethiopia
}

Submission: December 20, 2018; Published: January 11, 2019

*Corresponding author: Biruk Gobena, Ethiopian Environment and Forest Research Institute, Environmental Pollution Management Research Directorate, Ethiopia

\begin{abstract}
Water hyacinth is one of the world's worst aquatic weed that infests rivers, dams, lakes, wetlands and irrigation channels. It is aggravating losses of biodiversity through competing for nutrients with native species and habitat along with altering the physical environment specifically the water reservoirs. The cross-sectional study was done to quantify the role of utilizing water hyacinth as mulch at Bora woreda, May 2018. Data was collected using the observational checklist and questioner, and analyzed using Microsoft Excel Version 2010. The Bora Woreda farmers are cleansing more than six hectares of water hyacinth annually and meanwhile, they are saving about 6400.00 ETB per one hectare of onion cultivation land per year. The local farmers become a source of the possible solution to control water hyacinth attacking Koka Lake as they are benefiting economically.
\end{abstract}

Keywords: Water hyacinth; Mulch; Germination

\section{Introduction}

Water hyacinth (Eichhornia crassipes) is an erect, free-floating macrophyte, live at the air-water interface and form two distinct canopies: leaf canopies comprising above-water structures and root canopies comprising below water structures [1]. It is becoming a great threat due to its extremely rapid proliferation and congests growth, presenting serious challenges in navigation, irrigation, and power generation [2]. It is aggravating losses of biodiversity through competing for nutrient and feed with native species and habitat along with altering the physical environment, specifically the water reservoirs [3]. Lake Tana, Lake Shala and Lake Koka, Aba-Samuel dam reservoir, and Koka dam reservoir are some of Ethiopia major lakes attacked by Water hyacinth. Over one hundred hectares of Wonji Shewa Sugar Factory's irrigation water reservoirs and its secondary and tertiary irrigation water supplies together with its border and central drains were invaded by this weed. The weed inflicted versatile troubles such as annual excess loss of water estimated about 65,610 to $490,860 \mathrm{~m}^{3}$ which incur up to $2,482.83$ USD annually for management options [4]. Similarly, the problem is serious in Lake Koka and thirty seven percent of the lake is covered by water hyacinth. Consequently, to switch the expansion of water hyacinth various studies have been taken in Ethiopia. Majority of the studies were focused on technological production of machines to clean lakes covered by water hyacinth. Afework and his colleague were trying to develop long-term control strategy by using biological agents. So far, the study was realized a significant reduction of water hyacinth population, nevertheless, water lettuce (Pistastratiotes) became another problem which needs to be managed [5].

In other hand, studies on water hyacinth use practice were performed including using it for phytoremediation to remove chromium from wastewater. Also, in the past three years different studies were done on water hyacinth use i.e like using it for chromium removal by phytoremediation, converting to energy, compost, bricket, and pellet etc. [2]. In favor of this effort Bora woreda farmers, living around Koka Lake, are using water hyacinth as mulch in the process of onion germination for the last four years. Bora woreda is located in East Showa zone which is $260 \mathrm{~km}$ from Addis Ababa, the capital city of Ethiopia. One of major Ethiopian lake, Koka lake, is found mainly in the Dodo-wodera and Malima kebeles of Bora woreda. The lake is widely attacked by water hyacinth (locally called boche). Farmers in the Bora woreda largely rely on the cultivation of onion. An estimated total of 1950 hectare land of the woreda is cultivated with onion annually as the communities living around the lake reported. The average onion cultivation frequency is two up to three times per year. For this activity, the farmers have been using water hyacinth (boche) as a substitute for "Fila" (local name) which has been previously used for the mulching purpose. To cultivate one hectare of onion they need to collect approximately $6.37 \mathrm{~m}^{3}$ of water hyacinth. 
In onion seed germination process temperature plays an active role. While typically germination occurs within 7-10 days, soil temperature affects this process. For instance, the cooler the soil temperature, the longer it will take for onion seeds to germinate - up to two weeks. Warm soil temperatures, on the other hand, can trigger onion seed germination in as little as four days [6]. The water hyacinth cover helps the germination process by keeping heat and moisture at the optimum level.

Once germination was initiated, (typically after 6-8 days), they will collect water hyacinth mulch and reuse it two up to three times for mulching activity. Then they disperse and cultivate germinated onion on the prepared farmland. Finally, the repetitively used water hyacinth mulch will be discarded to decompose, though it will take a longer time to decompose, unlike other weeds. Assuming that

a) all Bora woredas' farmers cultivating onion will use water hyacinth (Boche) for onion germination initiation, as mulch,

b) the local farmers are cultivating in two terms per year,

c) the average height of water hyacinth is $40 \mathrm{~cm}$,

d) one bundle of Fila costs 10.00 ETB; the Bora Woreda farmers are cleansing more than six hectares of water hyacinth annually and saving about 6400.00 ETB per one hectare of onion cultivation land per year.

\section{Conclusion}

In this short communication, it was tried to reveal that the Bora woreda farmers become source of solution to control water hyacinth attacking Koka Lake. The local practice of the farmers could be an alternative management option of water hyacinth invasion. The authors recommend that the experience should be taken as best practice by other farmers. In addition, concerned bodies should give attention to such local management options which are emerging from the hosting local communities. Moreover, research institutes should take responsibility to upgrade this indigenous knowledge with in-depth scientific experiments and extension.

\section{References}

1. Center TD, Hill MP, Cordo H, Julien MH (2002) Water hyacinth. In: Driesche RV, et al. (Eds.), Biological Control of Invasive Plants in the Eastern United States. pp. 41-64.

2. Mahamadi C (2011) Water hyacinth as a biosorbent: A Review African Journal of Environmental Science and Technology 5(13): 1137-1145.

3. MOWR (Ministry of Water Resources) (2004) Koga Irrigation Project, Working paper nr 8, Night Storage Reservoirs. Accessible as hardcopy at Koga Irrigation Project Office in Merawi.

4. Yirefu F, Tafesse A, Gebeyehu T, Tessema T (2007) Distribution, Impact and Management of Water Hyacinth at Wonji-Shewa Sugar Factory. Eth J of Weed Mgt 1(1): 41-52.

5. Afework D, Tessema T, Yirefu F (2008) Efficacy of Integrated Water Hyacinth Management Strategies at Wonji-Shoa Sugar Factory. Eth J of Weed Mgt 2: 57-70.

6. Nikki T, (2015) Growing Onion Seed - Planting Onion Seeds in the Garden.

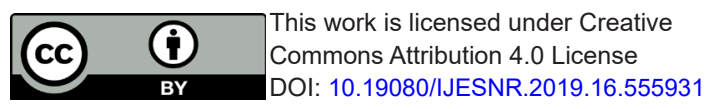

\begin{tabular}{l} 
Your next submission with Juniper Publishers \\
will reach you the below assets \\
- Quality Editorial service \\
- Swift Peer Review \\
- Reprints availability \\
- E-prints Service \\
- Manuscript Podcast for convenient understanding \\
- Global attainment for your research \\
- Manuscript accessibility in different formats \\
( Pdf, E-pub, Full Text, Audio) \\
- Unceasing customer service \\
Track the below URL for one-step submission \\
https://juniperpublishers.com/online-submission.php \\
\hline
\end{tabular}

